\title{
Disposal of Agro-Industrials Wastes as Soil Amendments
}

\author{
Ali Mekki, Fatma Arous, Fathi Aloui and Sami Sayadi \\ Laboratory of Bioprocesses, Center of Biotechnology of Sfax, AUF (PER-LBP), BP: 1177, 3018 Sfax, Tunisia
}

Received 2014-01-01; Revised 2014-01-08; Accepted 2014-01-11

\begin{abstract}
We investigated the fertilizing potential of three agro-industrial wastes (Compost (C), Dehydrated Manures (DM) and Digestate (D)) on soil properties, on seeds germination and the plants growth. Results showed that the addition of wastes modified several soil properties as $\mathrm{pH}$, Electrical Conductivity (EC), Water Retention Capacity (WRC) and Soil Organic Matter (SOM). Hence, SOM increase from $1.5 \%$ in unamended soil to $2,2.3$ and to $3.1 \%$ in soils amended with (D), with (DM) and with (C) respectively. A fast SOM biodegradation was illustrated in presence of compost where we noted a decrease of $20 \%$ of initial organic matter content. Besides, wastes improve strongly microbial and respirometric soil activities mainly in presence of DM and D. These same wastes stimulate seeds germination of two standard plants species (Tomato (Lycopersicon esculentum) and Alfalfa (Medicago sativa)). The growth levels of three cultivated plants species (Wheat (Triticum durum), Sorghum (Sorghum bicolor) and Alfalfa (Medicago sativa)) were enhanced in presence of wastes than those irrigated with water.
\end{abstract}

Keywords: Compost, Dehydrated Manures, Digestate, Fertilization, Soil

\section{INTRODUCTION}

Addition of organic materials of various origins has been one of the most common rehabilitation practices to improve soil properties (Weber et al., 2007). Celik et al. (2004) reported that organic matter addition improved soil aggregation, water-holding capacity, hydraulic conductivity, bulk density, the degree of compaction, fertility and resistance to water and wind erosion. Weil and Magdoff (2004) established that soil organic matter is crucial source of nutrients for the microflora,

However, the massive use of chemical fertilizers and intensification of cropping systems result in depletion of soil organic matter giving them a lower fertility and increased susceptibility to degradation (Sleutel et al., 2003). The alteration poses various problems, soil structural, agronomic and related fertility and crop production (Van-Camp et al., 2004; Annabi et al., 2007). microfauna and plants.

The use of organic wastes as compost, digestate and manures in agriculture could help fight against land degradation. Indeed, it is generally accepted that these substrates contribute to the maintenance of soil stability and they provide nutrients to crops. Some studies have been conducted in African and Asiatic semi-arid climates showing soil properties improvement and crop production enhancement under municipal solid waste compost treatment (Draogo et al., 2001; Sabir et al., 2013). According to Weber et al. (2007), good agricultural practices involve frequent applications of organic fertilizers as well as different kinds of compost. Annabi et al. (2007) reported that crop residues, manures and compost from organic wastes have been used to improve soil physical properties in croplands.

Similarly, Perez-Piqueres et al. (2006) stated that soil amendment with compost is an agronomically interesting practice as well as an attractive waste management strategy.

In Tunisia (North of Africa), climate is arid and soils are relatively poor in term of organic matter Corresponding Author: Ali Mekki, Laboratory of Bioprocesses, Center of Biotechnology of Sfax, AUF (PER-LBP), BP: 1177, 3018 Sfax, Tunisia Tel/Fax: + 21674874452 
while organic wastes are produced in a huge quantity (Mekki et al., 2008).

Then, one possible method of remediation and improvement of soils degraded situations is to use organic amendments such as fertilizers (Cherif et al., 2009; Mekki et al., 2009).

In this context, our aim was to investigate the best amendments of various biological wastes subjected to various treatments (compost produced from olive oil industry by-products, dehydrated manures and digestate) to use in the Tunisian dry climate. We compared the effects of three types of agro-industrial wastes on soil biochemical properties, seeds germination and plants growth.

\section{MATERIALS AND METHODS}

\subsection{Wastes Origin and Description}

In this study we used three different agro-industrial wastes.

\subsection{Compost}

The compost used in this study was consisting essentially by $55 \%$ of Olive Mill Wastewaters (OMW) sludge (from evaporation ponds of Agareb, Sfax, Tunisia), $18 \%$ of residual green wastes (as initial carbon substrate structuring) and $27 \%$ of dehydrated manures (from farmed chickens). The composting process used was a windrow composting.

\subsection{Digestate}

In this experimental study, two types of substrates feeding the digester were used and were as follows:

- The first consists of OMW from a discontinuous extraction system

- The second type is dehydrated manures from farmed chickens

The reactor used during processing was the Sequential Batch Reactor (SBR) widely used for treatment of effluents from slaughter houses, sewage, manures and slurry.

\subsection{Dehydrated Manures}

Dehydrated manures from farmed chickens (Sfax, Tunisia).

\subsection{Soil Origin and Description}

The studied soil located in the region of Sfax-Tunisia (North latitude $34^{\circ} 3^{\prime}$, East longitude $10^{\circ} 20^{\prime}$, the mean annual rainfall is $200 \mathrm{~mm}$ ). It is a sandy soil in both surface and depth, with a slightly alkaline $\mathrm{pH}$, a low electrical conductivity and is poor in organic matter content. The nitrogen, potassium and phosphorus were very low. Soil samples were collected (from an uncultivated plot), analyzed (for physico-chemical analyses) and immediately stored at $-4^{\circ} \mathrm{C}$ for microbiological and respirometric analyses.

\subsection{Physicochemical Analyses}

\subsubsection{Determination of $\mathrm{pH}$ and Electrical Conductivity (EC)}

The $\mathrm{pH}$ and EC of each sample (soil, compost, manures and digestate) were determined according to Peredes et al. (1987) standard method. The $\mathrm{pH}$ values were measured using a $\mathrm{pH}$ meter (Mettler Toledo MP 220). The EC values were measured by a conductivity meter (CONSORT).

\subsection{Determination of dry Matter and Water Content}

Samples dry matters and water contents were determined according to Sierra et al. (2001) standard method. Indeed, from 20 to $30 \mathrm{~g}$ of each wet sample $\left(\mathrm{m}_{1}\right)$ were introduced into a porcelain crucible mass $\left(\mathrm{m}_{0}\right)$. Drying at $105^{\circ} \mathrm{C}$ until constant weight $\left(\mathrm{m}_{2}\right)$ to determine the Dry Matter (DM) in (\%) and soil water content $(\mathrm{H}$ $\%$ ) by the following formulas:

$$
\operatorname{DM}(\%)=\left(\mathrm{m}_{2}-\mathrm{m}_{0} / \mathrm{m}_{1}-\mathrm{m}_{0}\right) \times 100 \mathrm{H}(\%)=100-\mathrm{DM}(\%)
$$

\subsection{Determination of Organic Matter (OM)}

Organics Matters (OM) were determined as the difference between the dry and residue (ash) from the calcination. Indeed, after the determination of dry matter, the same crucible of mass $\mathrm{m}_{2}$ was introduced in a furnace (Thermolyne 6000 Furnace type) at a temperature of $600^{\circ} \mathrm{C}$ for a minimum of $2 \mathrm{~h}$. The crucible has acquired a new mass $\mathrm{m}_{3}$ :

$$
\mathrm{OM}(\% \text { of } \mathrm{DM})=100 \times\left(\mathrm{m}_{2}-\mathrm{m}_{3}\right) /\left(\mathrm{m}_{2}-\mathrm{m}_{0}\right)
$$

\subsection{Determination of Mineral Matter (MM)}

Mineral Matter (MM) is defined as the difference between the dry matter and organic matter:

$$
\mathrm{MM}(\% \text { of DM) }=\mathrm{DM}-\mathrm{OM}(\% \mathrm{DM})
$$




\subsection{Determination of Total Organic Carbon (TOC)}

Total Organic Carbon (TOC) was determined by a multi analyzer N/C 1000, type Analytic Jena (Germany). Indeed, the analyzer multi N/C 1000 allows the determination of total carbon content in liquid or solid samples.

The sample was acidified with phosphoric acid $\left(\mathrm{H}_{3} \mathrm{PO}_{4}\right)$ to release Carbon dioxide $\left(\mathrm{CO}_{2}\right)$ before it is introduced into the analyzer. The combustion of an aliquot at high temperature in an oxygen flow to determine the TOC content in the sample.

\subsection{Determination of Total Nitrogen (TN)}

For the determination of total nitrogen, the Kjeldahl method has been applied (Kandeler, 1996). The first step is the sample mineralization by acid digestion (sulfuric acid) in the presence of a catalyst (selenium). Organic nitrogen is converted into Ammonium Sulfate $\left(\mathrm{NH}_{4}\right)_{2} \quad \mathrm{SO}_{4}$. By distilling the ammonium sulfate with an excess of concentrated $\mathrm{NaOH}(5 \mathrm{~N})$, Ammonia $\left(\mathrm{NH}_{3}\right)$ is released and carried by the current of water vapor. Ammonia is thus collected in a solution of boric acid $\left(\mathrm{H}_{3} \mathrm{BO}_{3}: 2 \%\right)$ by the equation of the following reaction:

$$
\mathrm{H}_{3} \mathrm{BO}_{3}+\mathrm{NH}_{3} \rightarrow\left(\mathrm{NH}_{4}\right) \mathrm{H}_{2} \mathrm{BO}_{3}
$$

The resulting solution is then titrated with hydrochloric acid $(\mathrm{HCl}: 0.01 \mathrm{M})$. The latter reacts with ammonium borate $\left[\left(\mathrm{NH}_{4}\right) \quad \mathrm{H}_{2} \mathrm{BO}_{3}\right]$ giving ammonium chloride $\left(\mathrm{NH}_{4}^{+} \mathrm{Cl}^{-}\right)$and undissociated boric acid $\left(\mathrm{H}_{3} \mathrm{BO}_{3}\right)$ according to the equation of the following reaction:

$$
\left(\mathrm{NH}_{4}\right) \mathrm{H}_{2} \mathrm{BO}_{3}+\mathrm{H}^{+}+\mathrm{Cl}^{-} \rightarrow \mathrm{NH}_{4}^{+} \mathrm{Cl}^{-}+\mathrm{H}_{3} \mathrm{BO}_{3}
$$

Thus for a mass ( $\mathrm{m}$ in grams) of the sample and a volume $(\mathrm{v}$ in $\mathrm{mL})$ of $\mathrm{HCl}(0.01 \mathrm{M})$ used for titration of ammonium ions, the percentage of total nitrogen is given by the formula Equation 1 (Kandeler, 1996):

$\% \mathrm{~N}(\mathrm{~g})=0,014 \times 4 \mathrm{v} / \mathrm{m}$

\subsection{Determination of Ammoniacal Nitrogen}

Ammoniacal Nitrogen $\left(\mathrm{N}-\mathrm{NH}_{4}\right)$ was determined according to (Kandeler, 1996) standard method. Phosphorus, iron, magnesium, potassium, calcium, sodium and chloride were determined by atomic absorption.

\subsection{Determination of Chemical Oxygen Demand (COD)}

The Chemical Oxygen Demand (COD) was determined. Yet COD is a measure of the oxidizability of a substance, expressed as the equivalent amount in oxygen of an oxidizing reagent consumed by the substance. Under fixed Laboratory conditions, COD is an oxidizability indicator used as a practical method to measure organic matter.

Chemical Oxygen Demand (COD) is a vital test for assessing the quality of effluents and wastewaters prior to discharge. The COD test predicts the oxygen requirement of the effluent and is used for the monitoring and control of discharges and for assessing treatment plant performance. COD was determined according to Sierra et al. (2001).

\subsection{Determination of Biochemical Oxygen Demand ( BOD $\left._{5}\right)$}

The Biochemical Oxygen Demand $\left(\mathrm{BOD}_{5}\right)$ assay is a standardized assessment of the amount of oxidizable or respirable organic matter in water. It is the amount of oxygen (in mg. $\mathrm{L}^{-1}$ ) required by bacteria to oxidize the organic molecules aerobically. Oxygen consumed by inorganic compounds is also measured by this test, which is why it is referred to as biochemical oxygen rather than just biological oxygen demand. It is used as an index of the amount of organic pollution of the water and is routinely employed to measure the efficiency of wastewater treatment plants at removing organic matter from wastewater or in assessing the effect of effluents on the trophic status of natural waters. $\mathrm{BOD}_{5}$ was determined by the manometric method with a respirometer (BSB-Controller Model 620 T) (WTW).

\subsection{Microbiological and Respirometric Analyses}

\subsubsection{Microbial Estimation}

Ten grams of each sample (soil, compost, compost/soil (at different dilutions), dehydrated manures, dehydrated manures/soil (at different dilutions) and digestate/soil (at different dilutions) was suspended in an erlenmeyer flask containing $90 \mathrm{~mL}$ of a sterile solution $(0.2 \%$ of sodium polyphosphate $\left(\mathrm{NaPO}_{3}\right) \mathrm{n}$ in distilled water, $\left.\mathrm{pH} 7.0\right)$ and $10 \mathrm{~g}$ of sterile glass beads ( $1.5 \mathrm{~mm}$ diameter). The flask was shaken at $200 \mathrm{rpm}$ for $2 \mathrm{~h}$. Serial 10 -fold dilutions of the samples in a $0.85 \% \mathrm{NaCl}$ solution were plated in triplicate on Plate Count Agar (PCA) medium at $30^{\circ} \mathrm{C}$ for total bacterial count, on Sabouraud containing 
chloramphenicol at $25^{\circ} \mathrm{C}$ for yeasts and moulds and on Désoxycholate Citrate Lactose (DCL) medium at $37^{\circ} \mathrm{C}$ for total coliforms. For spore-forming bacteria count, aliquots were heated for $10 \mathrm{~min}$ at $80^{\circ} \mathrm{C}$ before spreading on PCA and incubation at $37^{\circ} \mathrm{C}$.

Each sample was analyzed in duplicate and the dilution series were plated in triplicate for each medium. The results were expressed as Colony Forming Units (CFU) per gram of dried soil $\left(24 \mathrm{~h}\right.$ at $\left.105^{\circ} \mathrm{C}\right)$.

\subsubsection{Respirometric Analyses}

Respirometric measurements were determined for unamended soil and all substrates/soil mixtures (compost/soil, dehydrated manures/soil and digestate/soil) by placing $100 \mathrm{~g}$ of each sample in an hermetically sealed $2 \mathrm{~L}$ glass jar equipped with a $\mathrm{CO}_{2}$ trap (a glass tube containing $2 \mathrm{~mL}$ of $4 \mathrm{~N} \mathrm{NaOH}$ ). Samples were taken every 2 days during 15 days. Incubations of different samples were carried out in the dark at $25^{\circ} \mathrm{C}$. The $\mathrm{CO}_{2}$ evolved were determined by titrating $1 \mathrm{~mL}$ of the $\mathrm{NaOH}$ solution with $0.5 \mathrm{~N} \mathrm{HCl}$ (Kandeler, 1996).

\subsection{Germination Index Determination}

Effects of different used agro-industrial wastes on seeds germination of two standard plants species Tomato (Lycopersicon esculentum) and Alfalfa (Medicago sativa) were assessed by determination of the germination index according to Zucconi et al. (1981) standard method.

\subsection{Valorization Assays}

Effects of different used agro-industrial wastes on three cultivated plants species (Wheat (Triticum durum), Sorghum (Sorghum bicolor) and Alfalfa (Medicago sativa) were investigated.

\subsection{Statistical Analyses}

For physicochemical analyses, three replications were used for each parameter. For microbiological soil analyses, each soil sample was analyzed in duplicate and the dilution series were plated in triplicate for each medium. Data were analyzed using ANOVA procedure. Variance and standard deviation were determined using Genstat 5 (second edition for windows).

\section{RESULTS}

\subsection{Wastes Physicochemical Properties}

The compost used have an alkaline $\mathrm{pH}$, a high electrical conductivity and a $\mathrm{C} / \mathrm{N}$ ratio around 15 . The $\mathrm{pH}$ values are between 7 and 9 , the $\mathrm{C} / \mathrm{N}$ ratio reflect the decomposition and stabilization of organic matter. The rate of $\mathrm{NH}_{4}{ }^{+}$is lower the upper limit recommended for mature compost which is $400 \mathrm{mg} \cdot \mathrm{kg}^{-1}$. Used compost contains suitable levels of organic matter and nutrients $(\mathrm{N}, \mathrm{P}$ and $\mathrm{K})$. The values of heavy metals were lower than European standards (Table 1).

The digestate can be described as a source of organic nutrients rich in potassium, calcium and magnesium which are considered as good fertilizers. However, there is a low-phosphorus content that can be remedied by adding a phosphate fertilizer. Digestate heavy metal concentrations were lower than standard recommendation NFU 44-051 (Table 1).

Dehydrated manures used in this work were characterized by high levels of dry matter and high concentrations of nutrients. The nitrogen content is the highest in comparison with all other substrates mentioned above. Indeed, the nitrogen content of manures is greater than the minimum required by the standard NFU 42-001. It is alike for other nutrients such as $\mathrm{P}_{2} \mathrm{O}_{5}$ content of which is highly superior to standard (Table 1).

\subsection{Effects of Wastes on the Soil Physicochemical Properties}

The evolution of soil $\mathrm{pH}$ before and after incubation of different substrates was followed for 90 days under ambient conditions. Raw substrates have initial pHs more alkaline than the control soil with remarkable alkalinity of compost. This alkalinity decreases with incubation time and this applies especially for the digestate. However, after 90 days of incubation, $\mathrm{pHs}$ of raw substrates remain slightly basic. These substrates can be used as alkaline amendments limiting soil acidification. Indeed, these amendments contain Calcium $(\mathrm{Ca})$, Magnesium $(\mathrm{Mg})$ in addition to bases $\left(\mathrm{OH}^{-}, \mathrm{CO}_{2}^{-}\right)$which will neutralize soil acidity and influence it is $\mathrm{pH}$.

Slight variations in $\mathrm{pH}$ were observed for the three mixtures (1C/9S; 1DM/49S and 1D/4W/1S) compared to the control soil. Concerning the mixture $1 \mathrm{DM} / 49 \mathrm{~S}$, the $\mathrm{pH}$ does not undergo major changes during the incubation time to reach almost the same $\mathrm{pH}$ as that of the control soil. The $\mathrm{pH}$ of the mixture $1 \mathrm{C} / 9 \mathrm{~S}$ remains stable around 8 , while the mixture $1 \mathrm{D} / 4 \mathrm{~W}$ shows a remarkable $\mathrm{pH}$ decrease from 8.4 to 7.1 after 65 days of incubation to reach the same $\mathrm{pH}$ value as the control soil (8.1) after 90 days of incubation. The electrical conductivity provides an estimate of the total content of dissolved salts. The compost and the manures were rich in salts compared to the digestate which presents EC values almost to those of control soil. 
Ali Mekki et al. / American Journal of Environmental Science 9 (6): 458-469, 2013

Table 1. Physico-chemical characteristics of different agro-industrial wastes

\begin{tabular}{|c|c|c|c|}
\hline Characteristics & $\mathrm{C}$ & D & DM \\
\hline $\mathrm{pH}\left(25^{\circ} \mathrm{C}\right)$ & $9.16^{\mathrm{a}}$ & $7.21^{b}$ & $9.07^{\mathrm{a}}$ \\
\hline $\mathrm{EC}\left(\mathrm{dS} \mathrm{m}{ }^{-1}\right)\left(25^{\circ} \mathrm{C}\right)$ & $7.33^{\mathrm{a}}$ & $9.69^{\mathrm{b}}$ & $7.99^{\mathrm{a}}$ \\
\hline Dry matter $(\%)$ & $95.17^{\mathrm{b}}$ & $5.39^{\mathrm{a}}$ & $87.61^{\mathrm{b}}$ \\
\hline Organic matter (\%) & $13.55^{\mathrm{a}}$ & $2.86^{\mathrm{b}}$ & $39.59^{\mathrm{c}}$ \\
\hline Mineral matter & $81.62^{\mathrm{a}}$ & $2.53^{\mathrm{b}}$ & $48.02^{\mathrm{c}}$ \\
\hline Total Nitrogen Kjeldahl (\%) & $0.55^{\mathrm{a}}$ & $0.21^{\mathrm{a}}$ & $3.73^{\mathrm{b}}$ \\
\hline Ammoniacal nitrogen $(\%)$ & $0.046^{\mathrm{a}}$ & $0.18^{\mathrm{b}}$ & $1.32^{\mathrm{c}}$ \\
\hline Carbon/Nitrogen & $13.56^{\mathrm{a}}$ & $8.62^{\mathrm{b}}$ & $5.89^{\mathrm{b}}$ \\
\hline $\mathrm{P}\left(\mathrm{mg} \mathrm{L}^{-1}\right)$ & $4.10^{\mathrm{a}}$ & $2.00^{\mathrm{b}}$ & $3.10^{\mathrm{a}}$ \\
\hline $\mathrm{Ca}\left(\mathrm{g} \mathrm{L}^{-1}\right)$ & $3.34^{\mathrm{a}}$ & $3.75^{\mathrm{a}}$ & $6.40^{\mathrm{b}}$ \\
\hline $\mathrm{K}\left(\mathrm{g} \mathrm{L}^{-1}\right)$ & $2.24^{\mathrm{a}}$ & $1.40^{\mathrm{b}}$ & $5.80^{\mathrm{c}}$ \\
\hline $\mathrm{Na}\left(\mathrm{g} \mathrm{L}^{-1}\right)$ & $6.60^{\mathrm{a}}$ & $11.60^{\mathrm{b}}$ & $8.50^{\mathrm{a}}$ \\
\hline $\mathrm{Cl}\left(\mathrm{g} \mathrm{L}^{-1}\right)$ & $7.40^{\mathrm{a}}$ & $12.10^{\mathrm{b}}$ & $9.30^{\mathrm{a}}$ \\
\hline $\operatorname{Mg}\left(\mathrm{mg} \mathrm{L}^{-1}\right)$ & $3.10^{\mathrm{a}}$ & $2.70^{\mathrm{a}}$ & $5.10^{\mathrm{b}}$ \\
\hline $\mathrm{Fe}\left(\mathrm{mg} \mathrm{L}^{-1}\right)$ & $3.30^{\mathrm{a}}$ & $0.18^{\mathrm{b}}$ & $1.20^{\mathrm{c}}$ \\
\hline $\operatorname{Mn}\left(\mathrm{mg} \mathrm{L}^{-1}\right)$ & $0.12^{\mathrm{a}}$ & $0.08^{\mathrm{a}}$ & ND \\
\hline $\mathrm{Zn}(\mathrm{ppm})$ & $78.00^{\mathrm{a}}$ & $62.00^{\mathrm{a}}$ & ND \\
\hline $\mathrm{Cu}(\mathrm{ppm})$ & $1.70^{\mathrm{a}}$ & $0.27^{\mathrm{b}}$ & ND \\
\hline $\mathrm{Ni}(\mathrm{ppm})$ & $2.11^{\mathrm{a}}$ & $0.27^{b}$ & ND \\
\hline $\operatorname{COD}\left(\mathrm{g} \mathrm{L}^{-1}\right)$ & ND & 30.20 & ND \\
\hline $\mathrm{BOD}_{5}\left(\mathrm{~g} \mathrm{~L}^{-1}\right)$ & ND & 12.50 & ND \\
\hline
\end{tabular}

Standard deviation $<10 \%$; Means followed within the same row by the same small letter are not statistically different; C: Compost; D: Digestate; DM: Dehydrated Manures; ND: Not Determined

The amendment and/or dilution of the different substrates on the soil decrease their initials salinities with an average of 10 times (especially for compost and manures). Nevertheless after dilution and 90 days of incubation, soils amended with compost and manures have still high EC values compared to the soil amended with digestate (1D/4W) which presents EC values near those of control soil $\left(180 \mu \mathrm{S} . \mathrm{cm}^{-1}\right)$. The compost water content shows an increase until the third week and then it decreases gradually in a slow until the end of the experiment. For manures, we noticed almost stable moisture from the second week of incubation until the end of the experiment, due to the richness of this substrate on organic matter with high water retention capacity. In the case of soil amended with digestate the water content is important at the beginning of the experiment but decreases rapidly with time to reach the values of control soil at the end of the incubation. In the case of substrates/soil $(1 \mathrm{C} / 9 \mathrm{~S}$, $1 \mathrm{D} / 4 \mathrm{~W}$ and $1 \mathrm{DM} / 49 \mathrm{~S}$ ) mixtures, the added organic matter acts on the soil water retention capacity. Indeed, the water content increases by providing compost and manures compared with the control soil. Moisture rises from 3.02 and $2.51 \%$ at initial time to 6.45 and $7.35 \%$ at the end of the experiment respectively for soils amended with compost and manures.

The evolution of organic matter content of raw substrates demonstrates the compost and manures richness on $\mathrm{OM}$ in comparison to control soil and soil irrigated with digestate. The raw substrates OM levels constancy during incubation can be explained by the organic matter low mineralization prior amendment or dilution (Fig. 1a). Substrates/soils mixtures (1C/9S, $1 \mathrm{D} / 4 \mathrm{~W}$ and $1 \mathrm{DM} / 49 \mathrm{~S}$ ) showed very low OM levels compared to their raw states (especially for compost and manures). These OM showed mineralization kinetics more important for all mixtures along the experiment. Indeed, OM decrease is more marked and estimated at 20 and $6 \%$ for $1 \mathrm{C} / 9 \mathrm{~S}$ and $1 \mathrm{DM} / 49 \mathrm{~S}$, respectively (Fig. 1b).

Table 2 showed that soil total nitrogen content increases slightly over time for different substrates/soil mixtures. Total phosphorus average content of all control soil samples was around $552 \mathrm{ppm}$. After 90 days of incubation, an increase in total phosphorus content for the three mixtures $1 \mathrm{C} / 9 \mathrm{~S}$, $1 \mathrm{DM} / 49 \mathrm{~S}$ and $1 \mathrm{D} / 4 \mathrm{~W}$ were noted. Indeed, the dose of $1 \mathrm{DM} / 49 \mathrm{~S}$ favours an increase in total phosphorus by $55 \%$. For compost and digestate, total phosphorus increases by 50 and $5 \%$ respectively compared to initial levels. The potassium content increases by $1.42,1.5$ and $1.15 \%$ (at the beginning) to $1.51,1.55$ and $1.2 \%$ (after 65 days) alternately for $1 \mathrm{C} / 9 \mathrm{~S}, 1 \mathrm{DM} / 49 \mathrm{~S}$ and $1 \mathrm{D} / 4 \mathrm{~W} / \mathrm{S}$, then decreases to $1.37,1.47$ and $1.1 \%$ (after 90 days) for the same doses respectively (Table 2 ). 
Ali Mekki et al. / American Journal of Environmental Science 9 (6): 458-469, 2013

Table 2. Evolution of Total Nitrogen (TN), Phosphorus (P) and potassium (K) in wastes/soil mixtures: 1C/9S, 1DM/49S, 1D/4W/1S in function of time and in comparison with Control Soil (CS)

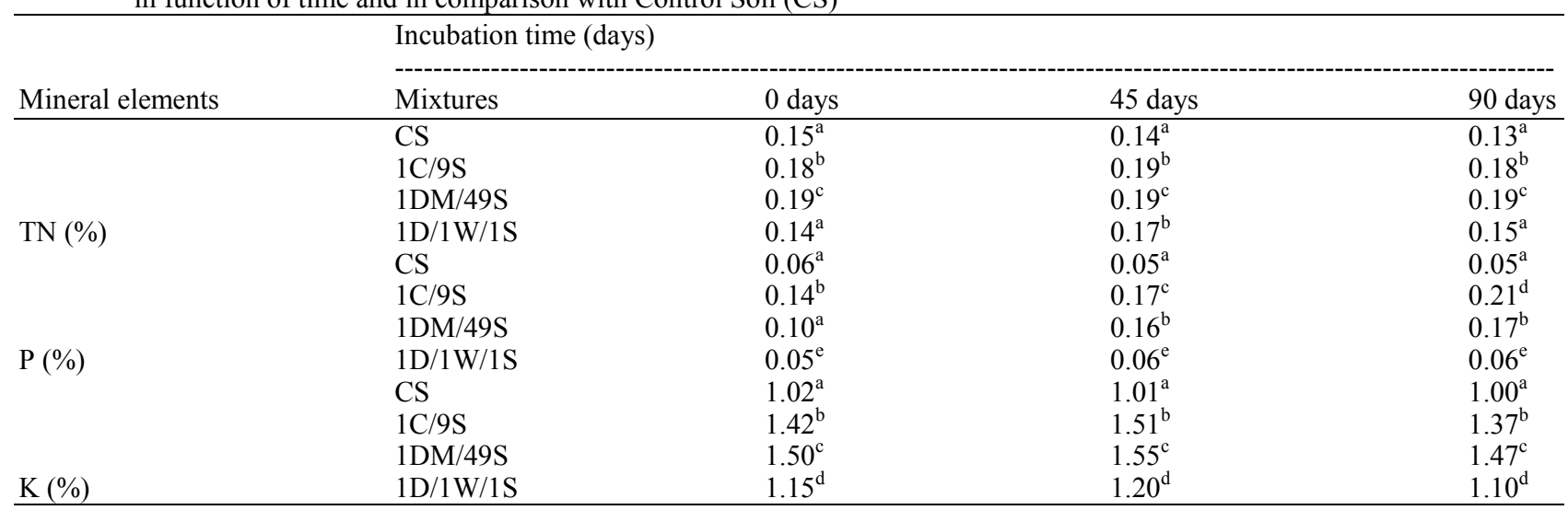

Standard deviation $<10 \%$, Means followed by the same small letter are not statistically different

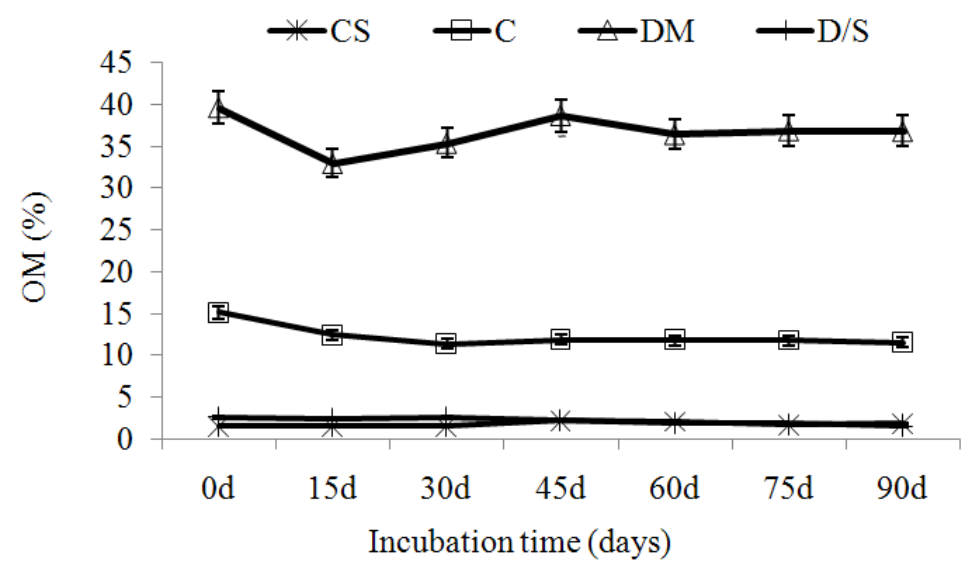

(a)

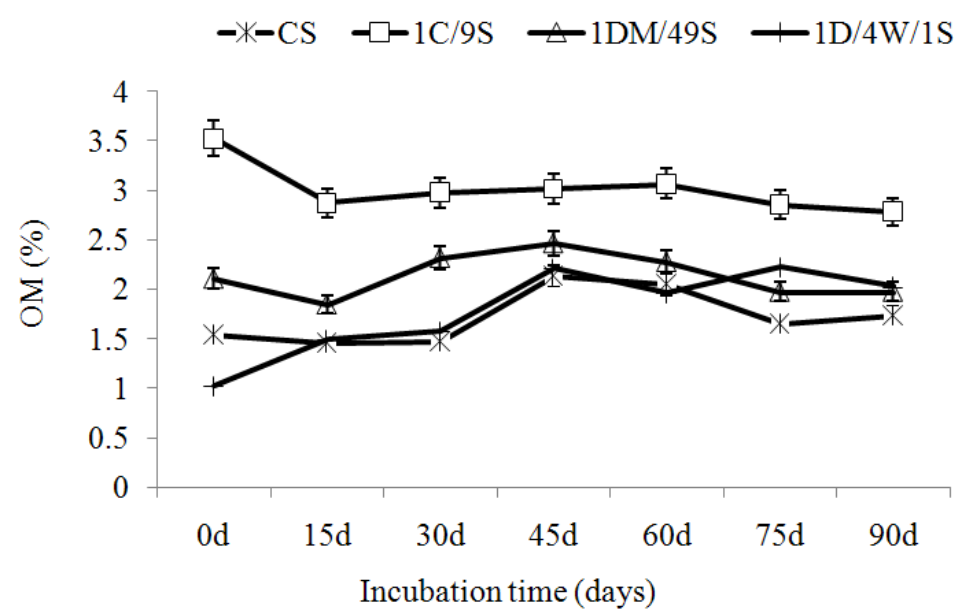

(b)

Fig. 1. (a) Raw wastes OM evolution as a function of time in comparison with Control Soil (CS). (b) Wastes/soil mixtures OM evolution as a function of time in comparison with Control Soil (CS) 


\subsection{Effects of Wastes on the Soil Microbiological Properties}

Total mesophilic microflora enumerated in the control soil was relatively low $\left(10^{3}-10^{4}\right.$ CFU.g ${ }^{-1}$ dry soil). The number of total enumerated bacteria increases with the addition of organic matter (mainly in the case of compost and manures) (Table 3). Indeed, after 90 days of incubation, total mesophilic microfloras counted increases by $13.66 \%$ in the mixture $1 \mathrm{C} / 9 \mathrm{~S}$ (10 times compared to the control soil), by $39.89 \%$ in the mixture $1 \mathrm{DM} / 49 \mathrm{~S}$ (30 times compared to the control soil) and by $6.7 \%$ in the mixture $1 \mathrm{D} / 4 \mathrm{~W}$ ( 5 times compared to the control soil). The results of enumeration of yeasts and moulds expressed in CFU. $\mathrm{g}^{-1}$ dry soil were presented in Table 3. At the beginning of incubation, low number of these germs was noted in all substrates/soil mixtures (especially $1 \mathrm{DM} / 49 \mathrm{~S}$ and $1 \mathrm{C} / 9 \mathrm{~S}$ ) compared to control soil. From the 48 day of incubation, we found an increase in the number of yeasts and moulds mainly in the mixture $1 \mathrm{D} / 4 \mathrm{~W}$. However, in the case of the mixture $1 \mathrm{DM} / 49 \mathrm{~S}$, the number of yeasts and moulds increases but remains below that of the control soil due to high water holding capacity of manures which makes the soil more lumpy and less permeable to the air. In the mixture $1 \mathrm{C} / 9 \mathrm{~S}$, the number of yeasts and moulds increases and exceeds that of the control soil (Table 3).

The number of spore-forming bacteria in the control soil was around $2.5810^{2}$ CFU $\mathrm{g}^{-1}$ dry soil. The contribution of different substrates, manures, compost and digestate does not seem to have a negative effect on these germs that are much more sensitive to water availability (Table 3). Control soil has a very low number of Total Coliforms (TC). The contribution of different substrates (digestate, compost and manures) causes a slight increase in the number of these bacteria (Table 3).

\subsection{Changes in Soils Respiration Rates}

Addition of substrates enhances significantly the soil organic matter content. This input of organic matter improves the respiratory activity (in terms of $\mathrm{mg} \mathrm{CO}_{2} \cdot \mathrm{g}^{-1}$ dry soil) compared to the control soil. This improvement is greater in the case of manures, most rich in organic matter mainly at nitrogenic form (Fig. 2a).

The specific respiration expressed in terms of amount of $\mathrm{CO}_{2}$ released from the existing amount of TOC in the control soil or substrates/soil mixtures express the rate of organic matter biodegradation.

Figure 2b clearly reflects the growing trend of specific respiration in different mixtures after an incubation period of 90 days in comparison to the control soil, very poor in organic matter. Further more, among the three added substrates, the digestate (at dose of $1 \mathrm{D} / 4 \mathrm{~W} / 1 \mathrm{~S}$ ) and manures (at dose of $1 \mathrm{DM} / 49 \mathrm{~S}$ ) showed the most important specific respiration rate that confirmed the non-toxicity of organic matter provided by manures and digestate and its rapid biodegradability.

Table 3. Microbiological counts in wastes/soil mixtures: 1C/9S, 1DM/49S, 1D/4W/1S in function of time and in comparison with Control Soil (CS)

\begin{tabular}{|c|c|c|c|c|}
\hline \multirow[b]{2}{*}{ Microbial types } & \multicolumn{4}{|c|}{ Incubation time (days) } \\
\hline & Mixtures & 0 days & 45days & 90 days \\
\hline & $\mathrm{CS}$ & $0.8^{\mathrm{a}}$ & $0.9^{\mathrm{a}}$ & $0.8^{\mathrm{a}}$ \\
\hline TMM & $1 \mathrm{C} / 9 \mathrm{~S}$ & $5.0^{\mathrm{a}}$ & $7.0^{\mathrm{b}}$ & $10.0^{\mathrm{c}}$ \\
\hline \multirow{3}{*}{$\left(10^{4} \mathrm{CFU} \mathrm{g}^{-1}\right.$ dry soil) } & $1 \mathrm{DM} / 49 \mathrm{~S}$ & $17.0^{\mathrm{a}}$ & $16.0^{\mathrm{a}}$ & $27.0^{\mathrm{b}}$ \\
\hline & $1 \mathrm{D} / 1 \mathrm{~W} / 1 \mathrm{~S}$ & $2.0^{\mathrm{a}}$ & $4.0^{\mathrm{b}}$ & $5.0^{\mathrm{b}}$ \\
\hline & $\mathrm{CS}$ & $1.8^{\mathrm{a}}$ & $1.5^{\mathrm{a}}$ & $1.7^{\mathrm{a}}$ \\
\hline Fungi & $1 \mathrm{C} / 9 \mathrm{~S}$ & $2.0^{\mathrm{a}}$ & $4.0^{\mathrm{b}}$ & $8.0^{\mathrm{c}}$ \\
\hline \multirow{3}{*}{$\left(10^{3}\right.$ CFU g g dry soil) } & $1 \mathrm{DM} / 49 \mathrm{~S}$ & $1.5^{\mathrm{a}}$ & $4.0^{\mathrm{b}}$ & $4.0^{\mathrm{b}}$ \\
\hline & $1 \mathrm{D} / 1 \mathrm{~W} / 1 \mathrm{~S}$ & $4.0^{\mathrm{a}}$ & $6.0^{\mathrm{a}}$ & $14.0^{\mathrm{b}}$ \\
\hline & $\mathrm{CS}$ & $3.0^{\mathrm{a}}$ & $2.0^{\mathrm{a}}$ & $2.4^{\mathrm{a}}$ \\
\hline SB & $1 \mathrm{C} / 9 \mathrm{~S}$ & $4.1^{\mathrm{b}}$ & $3.7^{\mathrm{b}}$ & $3.5^{\mathrm{b}}$ \\
\hline \multirow{3}{*}{$\left(10^{2} \mathrm{CFU} \mathrm{g}^{-1}\right.$ dry soil $)$} & $1 \mathrm{DM} / 49 \mathrm{~S}$ & $3.0^{\mathrm{c}}$ & $3.1^{\mathrm{c}}$ & $2.9^{\mathrm{c}}$ \\
\hline & $1 \mathrm{D} / 1 \mathrm{~W} / 1 \mathrm{~S}$ & $3.0^{\mathrm{d}}$ & $2.2^{\mathrm{d}}$ & $2.6^{\mathrm{d}}$ \\
\hline & $\mathrm{CS}$ & $0.1^{\mathrm{a}}$ & $0.2^{\mathrm{a}}$ & $0.2^{\mathrm{a}}$ \\
\hline & $1 \mathrm{C} / 9 \mathrm{~S}$ & $0.2^{\mathrm{b}}$ & $1.5^{\mathrm{b}}$ & $1.2^{\mathrm{b}}$ \\
\hline \multirow{2}{*}{$\left(10^{2}\right.$ CFU g ${ }^{-1}$ dry soil $)$} & $1 \mathrm{DM} / 49 \mathrm{~S}$ & $0.1^{\mathrm{a}}$ & $1.0^{\mathrm{b}}$ & $0.8^{\mathrm{c}}$ \\
\hline & $1 \mathrm{D} / 1 \mathrm{~W} / 1 \mathrm{~S}$ & $0.2^{\mathrm{a}}$ & $0.7^{\mathrm{b}}$ & $0.6^{\mathrm{b}}$ \\
\hline
\end{tabular}

Standard deviation $<10 \%$. Means followed by the same small letter are not statistically different; TMM: Total Mesophilic Microflora; SB: Spore forming Bacteria; TC: Total Coliforms 


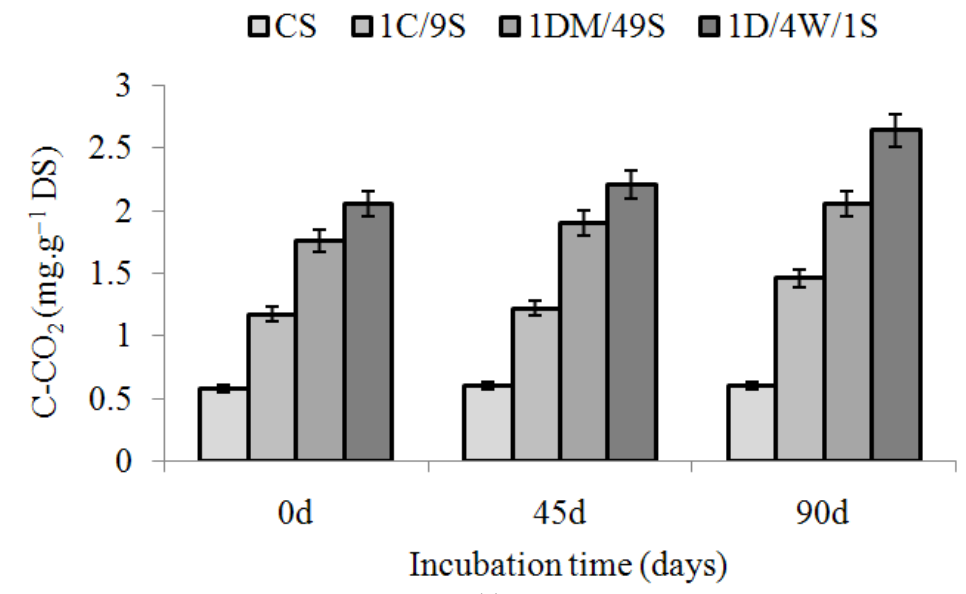

(a)

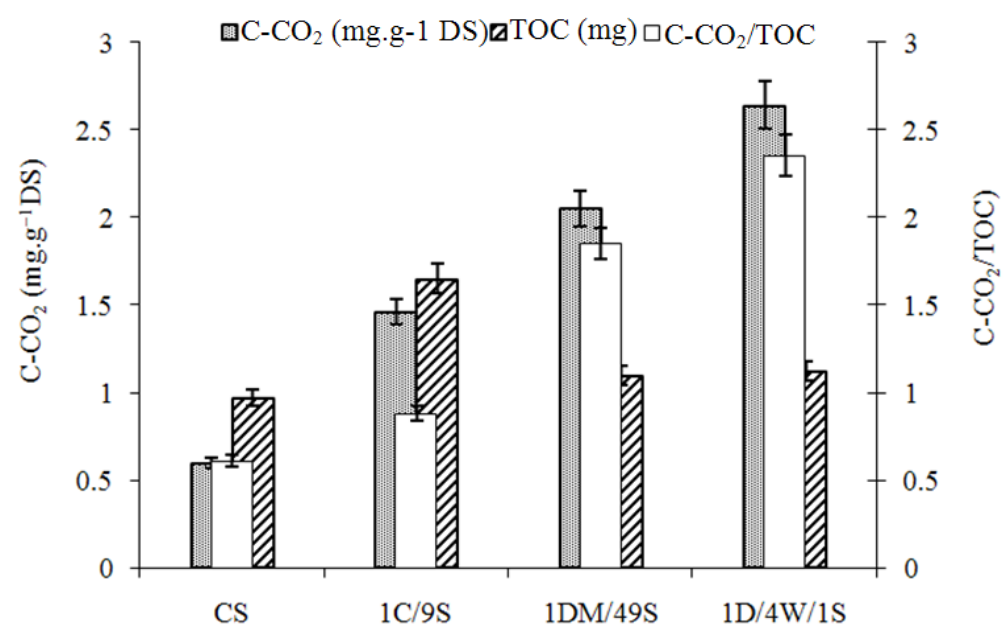

(b)

Fig. 2. (a) Wastes/soil mixtures $\mathrm{C}-\mathrm{CO}_{2}$ evolution as a function of time in comparison with Control Soil (CS). (b) Wastes/soil mixtures specific respiration after 90 days incubation in comparison with Control Soil (CS)

\subsection{Effects of Wastes on Seeds Germination and on Plants Growth}

The germination index of Alfalfa (Medicago sativa) and Tomato (Lycopersicon esculentum) increased gradually over time for all mixtures compost/soil to reach values above $50 \%$ after 45 days and above $80 \%$ after 90 days even in the raw compost. Optimal Germination Index (GIs) were observed in the mixture $1 \mathrm{C} / 9 \mathrm{~S}$ since after 90 days of experimentation GIs were around $185.97 \%$ and $195.91 \%$ respectively for Tomato and Alfalfa seeds.

The seeds germination of both species is zero when it is performed in the presence of raw manures or in
1DM/1S confirming the phytotoxicity of manures at the doses mentioned (raw manures and 1DM/1S). However, this phytotoxicity is progressively reduced over time by reducing the ratio manure/soil. At the proportion of 1DM/49S, GIs were optimal for the two tested species and were significantly higher than the control ones. Indeed, at this dose of manures, the GI varies between 162 and $164 \%$ for Tomato and Alfalfa, respectively.

Concerning the effects of different substrates on plants growth, the experiment was conducted in pots under ambient conditions. For each treatment, eight plants of each specie were selected for monitoring the evolution of different parameters during a culture period of 70 days. For Wheat plants species, the growth curves 
show a sigmoid shape substantially whose profile is quite variable depending on the amendment used. In the control soil, changes in the size of Wheat plants essentially follows a line of low slope, indicating a rapid entry into the linear phase without passing through a significant exponential phase. In the other substrates/soils mixtures, plant elongation curve has a sigmoid shape significantly. Also the slope of the exponential phase and changes in height throughout the growth cycle were much greater in amended soils. This could be explained by lack of nutrients in the control soil and were provided by the amendment.

However, from the beginning of the experiment, the growth of Wheat plants is more pronounced in soils amended with manures from other substrates. At the end of growth cycle and in the control group, the growth of Wheat plants stops at a final height of about $22 \mathrm{~cm}$. The final height of plants grown in presence of manures stabilized at $36 \mathrm{~cm}$. This length is higher than that achieved by the amendment in compost and digestate. As for Sorghum plants, plant height at the beginning of the experiment is quite similar, except for plants grown in the presence of compost have lower growth. The growth curves of plants evolve in the same way in the soil amended with digestate and in the control soil.

In the case of soils amended with compost, despite the initial heights were lower than those of the control soil, it was found that during the exponential phase the average height of these plants exceeds that of the control. At the end of the experiment, growth of control plants stops at a height of $27 \mathrm{~cm}$. The contribution of manures promotes better plant growth up to $54 \mathrm{~cm}$ after 70 days of culture, followed by compost with height of $49 \mathrm{~cm}$ and finally the digestate $(33 \mathrm{~cm})$. These amendments not only enhances soil organic matter content, but also the elements necessary for plant growth such as iron, manganese, copper, zinc and boron. Positive effects of the substrates were also demonstrated in Alfalfa plants growth curves which begin with the same height at the start of the experiment but after 56 days, we get a growth of plants 2 times important in the mixture $1 \mathrm{C} / 9 \mathrm{~S}$ and 2.5 times greater in the presence of digestate in comparison with those measured in the control soil.

\section{DISCUSSION}

The compost used have an alkaline $\mathrm{pH}$, In line with this, Cayuela et al. (2006) stated that in a successful composting of waste from the olive industry, the $\mathrm{pH}$ values are between 7 and 9. Huang et al. (2006) reported that changes in the $\mathrm{C} / \mathrm{N}$ ratio reflect the decomposition and stabilization of organic matter. Hachicha et al. (2008) showed that the loss of water during the composting thermophilic phase generates salts concentration in the remaining material which causes therefore an increase in salinity and so the electrical conductivity. The rate of $\mathrm{NH}_{4}^{+}$is lower the upper limit recommended for mature compost which is $400 \mathrm{mg} \cdot \mathrm{kg}^{-1}$ (Zucconi and Bertoldi, 1987).

Methanization is a conservative process for such elements not included in the composition of the biogas methane $\left(\mathrm{CH}_{4}\right)$, which explains the maintenance of nitrogen content in this effluent. Thus, during the process of anaerobic digestion, only part of the original organic matter is completely degraded, the rest can be considered as a potential fertilizer of agricultural land (Erhart et al., 2005).

Dehydrated manures used in this work were characterized by high levels of dry matter and high concentrations of nutrients. The wealth of dehydrated manures in nitrogen, phosphorus, potassium and calcium makes them a potential amendment to the soil poor in these elements (Weber et al., 2007).

Amendments contain Calcium (Ca), Magnesium $(\mathrm{Mg})$ in addition to bases $\left(\mathrm{OH}^{-}, \mathrm{CO}_{2}^{-}\right)$which will neutralize soil acidity and influence it is $\mathrm{pH}$. Calcium and bases contribute both to improving the structure of the clay-humus complex, which facilitates soil aeration and drying and intensify microbial life (Dinon and Gerstmans, 2008). According to Mekki et al. (2009), changes in $\mathrm{pH}$ depend on $\mathrm{H}^{+}$concentration from organic matter oxidation. It should be noted that the optimum soil $\mathrm{pH}$ is between 6 and 7 because the majority of nutrients available to plants in this $\mathrm{pH}$ range (Dinon and Gerstmans, 2008).

It is well known that organic fertilization contributes to land salinity (Hachicha et al., 2008; Montserrat et al., 2006). However, the EC values of amended soils were all below the inhibitory value (estimated at $2 \mathrm{mS} \mathrm{cm}^{-1}$ ) for sensitive crops (Taccari et al., 2009).

Soil water holding capacity is the amount of water capable of being retained by the soil in place (Ammar et al., 2004). The increase in soil water holding capacity compared to the control soil is explained by the affinity of the components of organic matter in water (organic matter hydrophilic character). In this way, Ammar et al. (2004) reported that the incorporation of organic matter in the soil increases the amount of water retained and the capacity increases to $30 \%$.

The Soil Organic Matter (SOM) consists of a mixture of microorganisms, plants and animals residues at 
various stages of decomposition. The evolution of organic matter content of raw substrates demonstrates the compost and manures richness on $\mathrm{OM}$ in comparison to control soil and soil irrigated with digestate. The raw substrates OM levels constancy during incubation can be explained by the organic matter low mineralization prior amendment or dilution. Thus, decreases in OM levels can be explained by their biodegradation by soil microflora (Beck-Friis et al., 2003; Erhart et al., 2005). The increase in potassium content can be explained by the binding of $\mathrm{K}^{+}$ions from the mineralization of organic matter on the exchange complex and the decrease of cations exchange capacity by the organic matter degradation (Halilat et al., 2000).

Microorganisms influence differently the structure and biological activity of soil according to their types, their metabolism and their synthesis products (Mekki et al., 2006). Fungi have the ability to bind soil particles via several mechanisms (mechanical retention, accession by the fungal glues). Indeed, many fungi secrete substances with high tack such as polysaccharides and gums witch consolidate the soil structure (Degens, 1997).

However, in the case of the mixture $1 \mathrm{DM} / 49 \mathrm{~S}$, the number of yeasts and moulds increases but remains below that of the control soil due to high water holding capacity of manures which makes the soil more lumpy and less permeable to the air. Indeed, several families of fungi are identified as having a low affinity for water mainly Basidiomycetes and Actinomycetes (Smits et al., 2003).

In soil, heterotrophic respiration is the process that allows the decomposition of litter (crop residues in agricultural soil) and organic matter under the action of micro-organisms that subsist there. In the presence of oxygen uptake and degradation of substrates by microorganisms accompanied by production of $\mathrm{CO}_{2}$. The rate of $\mathrm{C}-\mathrm{CO}_{2}$ released is strongly influenced by the amount of organic matter in soil (Liu et al., 2013).

With organic matter content of about $1.5 \%$, control soil can be considered so poor in OM, which explains its low respiratory activity (Sierra et al., 2001).

The germination index increased gradually over time for all mixtures compost/soil and even in the raw compost which indicates that the compost is not phytotoxic (Zucconi et al., 1981). These results were consistent with those found by (Abid and Sayadi, 2006) which showed that the addition of compost from olive mill waste water had positive effects on growth of Tomato plants.
We found that soil amendment with the digestate is very encouraging for crops growth. In this context, Degens (1997) showed that treatment of olive mill wastewaters either by aerobic or anaerobic process generates detoxified product. This feature seems to be retained in the digestate from co-digestion of manure and olive mill wastewaters. These treated waters are rich in water and minerals essential for soil fertilization and for plants growth.

\section{CONCLUSION}

Soil biochemical properties can be greatly affected by the addition of organic amendments. This study shows that the application of three agro-industrial wastes in an arid climate modifies structural and physico-chemical soil properties, stimulates seeds germination and improves plants growth.

High soil Organic Matter Concentration (SOM) and soil fertility were positively correlated with high hydraulic conductivity and water retention capacity. The treatments that significantly increased SOM concentration were also the ones that amplified soil salinity especially in presence of compost. Although the positive effect of SOM on soil aggregation is well known, this study did not identify a strong relation-ship between these two properties.

Finally, this study indicates the ecological importance of organic materials addition especially in an arid environment, even when applied in relatively moderate quantities, for the improvement of soil biochemical properties and crops growth.

\section{ACKNOWLEDGMENT}

This research was funded by contracts programmes (MESRS, Tunisia).

\section{REFERENCES}

Abid, N. and S. Sayadi, 2006. Detrimental effect of olive mill wastewater on the composting process of agricultural wastes. Waste Manage., 26: 1099-1107. DOI: 10.1016/j.wasman.2005.06.015

Ammar, E., M. Nasri and K. Medhioub, 2004. Isolation of Enterobacteria able to degrade simple aromatic compounds from the wastewater from olive oil extraction. World J. Microbiol. Biotechnol., 21: 251259. DOI: $10.1007 / \mathrm{s} 11274-004-3625-\mathrm{y}$ 
Annabi, M., S. Houot, C. Francou, M. Poitrenaud and Y.L. Bissonnais, 2007. Soil aggregate stability improvement with urban composts of different maturities. Soil Sci. Soc. Am. J., 71: 413-423. DOI: 10.2136/sssaj2006.0161

Beck-Friis, B.S., H. Johnson, Y.E. Kirchmann and H. Smars, 2003. Composting of source-separated housold organics at different oxygen levels: Gaining and understanding of the emission dynamics. Compos. Sci. Utilizat., 11: 41-50. DOI: 10.1080/1065657X.2003.10702108

Cayuela, M.L., M.A. Sanchez-Monedero and A. Roig, 2006. Evaluation of two different aeration systems for composting two-phase olive mill wastes. Process Biochem., 41: 616-623. DOI: 10.1016/j.procbio.2005.08.007

Celik, I., I. Ortas and S. Kilic, 2004. Effects of composts, mycorrhiza, manure and fertilizer on some physical properties of Chromoxerert soil. Soil Tillage Res., 78: 59-67. DOI: 10.1016/j.still.2004.02.012

Cherif, H., F. Ayaria, H. Ouzaria, M. Marzoratib, L. Brusettib and A. Hassena et al., 2009. Effects of municipal solid waste compost, farmyard manure and chemical fertilizers on wheat growth, soil composition and soil bacterial characteristics under Tunisian arid climate. Eur. J. Soil Biol., 45: 138145. DOI: 10.1016/j.ejsobi.2008.11.003

Degens, B.P., 1997. Macro-aggregation of soils by biological bonding and binding mechanisms and the factors affecting these: A review. Australian J. Soil Res., 35: 431-459. DOI : 10.1071/S96016

Dinon, E. and A. Gerstmans, 2008. Linfluence du pH sur l'assimilation des elements nutritifs du sol par les plantes et sur la variété des plantes. Universitede Liège, Printemps Des Sciences.

Draogo, E., A. Mando and N.P. Zombre, 2001. Use of compost to improve soil properties and crop productivity under low input agricultural system in West Africa. Agric. Ecosyst. Environ., 84: 259-266. DOI: $10.1016 / \mathrm{S} 0167-8809(00) 00246-2$

Erhart, E., W. Hartl and B. Putz, 2005. Biowaste compost affects yields nitrogen supply during the vegetation period and crop quality of agricultural crops. Eur. J. Agron., 23: 305-314. DOI: 10.1016/j.eja.2005.01.002

Hachicha, S., F. Sallemi, K. Medhioub, R. Hachicha and E. Ammar, 2008. Quality assessment of composts prepared with olive mill wastewater and agricultural wastes. Waste Manage., 29: 59-66. DOI: 10.1016/j.wasman.2007.12.007
Halilat, M.T., M A. Dogar and M. Adraoui, 2000. Effet de lazote, du potassium et de leur interaction sur la nutrition du blé sur sol sableux du desert algerien. Revue Homme, Terre Eaux, 30: 32-39.

Huang, G.F., Q.T. Wu, J.W.C. Wong and B. Nagar, 2006. Transformation of organic matter during cocomposting of pig manure with sawdust. Bioresource Technol., 97: 1834-1842. DOI: 10.1016/j.biortech.2005.08.024

Kandeler, E., 1996. Total Nitrogen. In: Methods in Soil Biology, Schinner, F., R. Ohlinger, E. Kandeler and R. Margesin (Eds.), Springer, Berlin, ISBN-10: 3642646336, pp: 406-408.

Liu, Y., L. Yang, D. Gu, W. Wu and X. Wan et al., 2013. Influence of tillage practice on soil $\mathrm{CO}_{2}$ emission rate and soil characteristics in a dry land wheat field. Int. J. Agric. Biol., 15: 680-686.

Mekki, A., A. Dhouib and S. Sayadi, 2006. Changes in microbial and soil properties following amendment with treated and untreated olive mill wastewater. Microbiol. Res., 161: 93-101. DOI: 10.1016/j.micres.2005.06.001

Mekki, A., A. Dhouib and S. Sayadi, 2009. Evolution of several soil properties following amendment with olive mill wastewater. Progress Natural Sci., 19: 1515-1521. DOI: 10.1016/j.pnsc.2009.04.014

Mekki, A., A. Dhouib, F. Feki and S. Sayadi, 2008. Assessment of toxicity of the untreated and treated olive mill wastewaters and soil irrigated by using microbiotests. Ecotoxicol. Environ. Safety, 69: 488-495. DOI: 10.1016/j.ecoenv.2007.04.008

Montserrat, G., E. Marti, J. Sierra, M.A. Garau and R. Cruanas, 2006. Discriminating inhibitory from enhancing effects in respirometry assays from metal polluted-sewage sludge amended soils. Applied Soil Ecol., 34: 52-61. DOI: 10.1016/j.apsoil.2005.12.005

Peredes, M.J., E. Moreno, A. Ramos-Cormenzana and J. Martinez, 1987. Characteristics of soil after pollution with waste waters from olive oil extraction plants. Chemosphere, 16: 1557-1564. DOI: 10.1016/0045-6535(87)90096-8

Perez-Piqueres, A., V. Edel-Hermann, C. Alabouvette and C. Steinberg, 2006. Response of soil microbial communities to compost amendments. Soil Biol. Biochem., 38: 460-470. DOI: 10.1016/j.soilbio.2005.05.025 
Sabir, M., M.M. Hanafi, T. Aziz, H.R. Ahmad and M. Zia-Ur-Rehman et al., 2013. Comparative effect of activated carbon, pressmud and poultry manure on immobilization and concentration of metals in maize (Zea mays) grown on contaminated soil. Int. J. Agric. Biol., 15: 559-564.

Sierra, J., E. Marti, G. Montserrat, R. Crauanas and M.A. Garau, 2001. Characterization and evolution of a soil affected by olive oil mill wastewater disposal. Sci. Total Environ., 279: 207-214. DOI: 10.1016/S0048-9697(01)00783-5

Sleutel, S., S. De Neve and G. Hofmann, 2003. Estimates of carbon stock changes in Belgian cropland. Soil Use Manage., 19: 166-171. DOI: 10.1079/SUM2003187

Smits, T.H.M., L.Y. Wick, H. Harms and C. Keel, 2003. Characterization of the surface hydrophobicity of filamentous fungi. Environ. Microbiol., 5: 85-91. DOI: 10.1046/j.1462-2920.2003.00389.x

Taccari, M., M. Stringini, F. Comitini and M. Ciani, 2009. Effect of Phanerochaete chrysosporium inoculation during maturation of cocomposted agricultural wastes mixed with olive mill wastewater. Waste Manage., 29: 1615-1621. DOI: 10.1016/j.wasman.2008.12.014
Van-Camp, L., B. Bujarrabal, R. Gentille, R.J.A. Jones and L. Montanarella et al., 2004. Reports of the technical working groups established under the thematic strategy for soil protection. Proceedings of the III: Organic Matter. Luxembourg: Office for Official Publications of the European Communities, pp: 311-496.

Weber, J., A. Karczewska, J. Drozd, M. Licznar and E. Jamroz et al., 2007. Agricultural and ecological aspects of a sandy soil as affected by the application of municipal solid waste composts. Soil Biol. Biochem., 39: 1294-1302. DOI: 10.1016/j.soilbio.2006.12.005

Weil, R. and F. Magdoff, 2004. Significance of Soil Organic Matter to Soil Quality and Health. In: Soil Organic Matter in Sustainable Agriculture, CRC Press, Boca Raton, FL, USA.

Zucconi, F. and M. Bertoldi, 1987. Compost Specification for the Production and Characterization of Compost from Municipal Solid Waste. In: Compost, Production, Quality and Use, De Bertoldi, M., P. L'hermite and F. Zucconi (Eds.), Elsevier, London, pp: 30-50.

Zucconi, F., M. Forte, A. Monac and M. Beritodi, 1981. Biological evaluation of compost maturity. Biocycle, 22: 27-29. 